\title{
ASYMMETRIC IMPACT OF INVESTOR SENTIMENT ON BRAZILIAN STOCK MARKET VOLATILITY
}

\author{
TALIEH S. V. FERREIRA ${ }^{1}$ \\ (iD) https://orcid.org/0000-0002-4621-3533 \\ MÁRCIO A. V. MACHADO ${ }^{1}$ \\ (iD https://orcid.org/0000-0003-2635-5240 \\ POLYANDRA Z. P. SILVA \\ (iD) https://orcid.org/0000-0002-9520-7826
}

To cite this paper: Ferreira, T. S. V., Machado, M. A. V., \& Silva, P. Z. P. (2021). Asymmetric impact of investor sentiment on Brazilian stock market volatility. Revista de Administração Mackenzie, 22 (4), 1-28. doi:10.1590/1678-6971/eRAMF210208

Submission: Dec. 18, 2019. Acceptance: Oct. 18, 2020.

\footnotetext{
1 Federal University of Paraíba (UFPB), João Pessoa, PB, Brazil.

2 Federal University of Cariri (Ufca), Juazeiro do Norte, CE, Brazil.
}

\section{(cc) BY This is an open-access article distributed under the terms of the Creative Commons Attribution License.}

\footnotetext{
This paper may be copied, distributed, displayed, transmitted or adapted for any purpose, even commercially, if provided, in a clear and explicit way, the name of the journal, the edition, the year and the pages on which the paper was originally published, but not suggesting that RAM endorses paper reuse. This licensing term should be made explicit in cases of reuse or distribution to third parties.

Este artigo pode ser copiado, distribuído, exibido, transmitido ou adaptado para qualquer fim, mesmo que comercial, desde que citados, de forma clara e explícita, o nome da revista, a edição, o ano e as páginas nas quais o artigo foi publicado originalmente, mas sem sugerir que a RAM endosse a reutilização do artigo. Esse termo de licenciamento deve ser explicitado para os casos de reutilização ou distribuição para terceiros.
} 


\section{ABSTRACT}

Purpose: The purpose of this study was to analyze the effect of investor sentiment on the volatility of the Brazilian stock market. Specifically, it aimed to identify if the asymmetric behavior of sentiment could be observed in emerging markets, considering companies that have characteristics that are difficult to price.

Originality/value: Unlike most studies on investor sentiment, this study focuses on its impact on the stock market volatility, as well as on the characteristics of companies associated with difficult pricing.

Design/methodology/approach: The volatility of the IBRX100 index was used to represent the Brazilian stock market, and as a proxy for investor sentiment it was selected Miranda's index (2018), based on market data. Data were estimated using the two-stage least squares (MQ2E) technique to address endogeneity problems. Finally, the volatility of companies with difficult-to-price characteristics was segregated to analyze their sensitivity to sentiment.

Findings: The results indicate that sentiment has a negative and significant relationship with the volatility of the Brazilian market, as well as evidences an asymmetrical behavior, being statistically stronger in pessimistic periods. Additional analyzes evidence that the explanatory sentiment capacity is sensitive to companies' characteristics, but only companies with a high book-to-market ratio showed asymmetric behavior, as expected by the literature. The portfolios segmented by size and illiquidity maintained an asymmetric behavior, but it was the volatility of the large companies and the less illiquid ones that were best explained by sentiment, indicating that the Brazilian market has distinctive characteristics in relation to developed markets.

\section{KEYWORDS}

Volatility. Investor sentiment. Asymmetry. Asset pricing. Mispricing. 


\section{INTRODUCTION}

Understanding market volatility is of fundamental importance to determine the cost of capital and evaluate investment-related decisions (Aydogan, 2017). It can be impacted by quantitative and qualitative information, according to its value relevance (Galdi \& Gonçalves, 2018). In view of the difficulty of traditional models in explaining market volatility, new factors are gaining importance, being investor sentiment one of these factors (Piccoli, Costa, Silva, \& Cruz, 2018). After the 1980s, the literature started to consider that certain phenomena and market patterns, defined as anomalies, could be explained by peaks of investor irrationality driven by his/her sentiment.

The sentiment would cause a deviation of the price from its fundamentals and a non-homogeneous interpretation of the information, consequently increasing assets volatility and generating temporary mispricing (Baker \& Wurgler, 2006; Kumari \& Mahakud, 2015). In this context, investor sentiment can be understood as the component of assets' price that is not justified by its fundamental (Smales, 2016) and as a systematic risk of assets that are priced by the market (Lee, Jiang, \& Indro, 2002; Schneller, Heiden, \& Hamid, 2018; Yu \& Yuan, 2011).

In the literature, there are two types of investors: less sophisticated investors (noise traders) who have random beliefs about the return on assets and are more susceptible to sentiment; and sophisticated investors, who perform rational arbitrageurs (Johnman, Vanstone, \& Gepp, 2018) and are not impacted by the sentiment. These elements act in the pricing process generating respectively a noise and a signal. Empirical evidence has shown that changes in noise traders' sentiment can result in a market volatility increase and temporary deviations of stock prices from their fundamentals (De Long, Shleiger, Summers, \& Waldmann, 1990).

However, it seems that the ability of investor sentiment to explain asset volatility changes depending on whether investor sentiment is optimistic or pessimistic, indicating an asymmetric explanatory capability on volatility (Smales, 2016). In this study, asymmetry refers to the reduction, total or partial, of the explanatory capacity of the investors' sentiment about the volatility of the Brazilian stock market. This asymmetry can occur when two factors are considered: changes in the sentiment between optimistic and pessimistic and when specific companies characteristics associated with pricing difficulties are considered (Aydogan, 2017; Baker \& Wurgler, 2006, 2007; Kumari \& Mahakud, 2015; Lee et al., 2002; Piccoli et al., 2018; Smales, 2016; Schneller et al., 2018; Yu \& Yuan, 2011). 
The asymmetric behavior would appear, given that, in periods of optimistic sentiment, there is a higher entry of noise traders and lower volatility, while in periods of pessimistic sentiment, there is greater uncertainty and, consequently, greater volatility (De Long et al., 1990). Furthermore, the markets are inefficient and have arbitrage limitations allowing factors associated with uncertainties to make them more volatile, increasing the significance of these relationships when sentiment is pessimistic (Aydogan, 2017; Lee et al., 2002; Smales, 2016; Yu \& Yuan, 2011).

Regarding companies' characteristics, Baker and Wurgler (2006) observed that companies that have characteristics associated with difficult pricing are evaluated in a non-homogenous way, allowing investor's sentiment to interfere with greater intensity in their pricing. In this sense, previous studies confirmed that, in some markets, the investor sentiment is more significant to explain the volatility of new companies in terms of listing, with a smaller size, higher growth pattern, and other characteristics that may cause uncertainties in their valuation compared to other companies (Baker \& Wurgler, 2006, 2007; Piccoli et al., 2018).

Therefore, this article aims to analyze the behavior of investor sentiment in the volatility of the Brazilian stock market. Specifically, it intends to verify whether variations in investor sentiment alter its explanatory capacity over market volatility and whether the sentiment explanatory power presents an asymmetric behavior when groups of companies defined from characteristics associated with difficulty pricing are considered. The sampling period comprises monthly data between January 2006 and December 2017, given the unavailability of the investor sentiment index in other periods.

The results show that investor sentiment has an asymmetric explanatory capacity over volatility, with greater intensity when the sentiment is pessimistic. Likewise, the sentiment evidenced asymmetric explanatory capacity when we considered different groups of companies formed based on their characteristics. However, only one of the characteristics showed results in line with the literature. The volatility of companies with high growth patterns, a characteristic associated with difficult pricing, was explained by investor sentiment, while with its opposite portfolio, there were no significant relationships. For size and illiquidity characteristics, we identified significant relationships between the sentiment and volatility of large companies and with less illiquidity, opposite to what we expected. This result can possibly be justified by the way investors operate in the Brazilian market, as they concentrate their investments in companies that are more accompanied by analysts and that enable capital reallocation with agility (Machado \& Medeiros, 2011). 
This study contributes to the advancement of investor sentiment literature because, unlike most studies that focus on the impact of sentiment on the stock price, this one seeks to document its effect on market volatility. From this perspective, it is possible to highlight the importance of investor sentiment as a factor associated with systematic risk and its pricing in the Brazilian market. This identification gains greater relevance in emerging markets, given their greater potential of mispricing and due to their distinct characteristics of developed markets in terms of financial uncertainty, trade-off between risk and return, and volatility (Galdi \& Gonçalves, 2018).

In addition, a greater understanding and documentation of the factors that explain the volatility of a market is relevant to enable the identification of optimal portfolios that diversify risk exposure and the selection of protection instruments. Thus, if the explanatory capacity of investor sentiment about volatility is confirmed, it is necessary to consider it in pricing models. Otherwise, it is likely that inaccurate asset price projections are made, and sub-optimal portfolios are selected (Kumari \& Mahakud, 2015).

The sentiment proxy utilized can also be considered a differential of this study, as the index is based on market factors, filling an important gap pointed out in the literature (Piccoli et al., 2018) that deals with the weaknesses found in the use of proxies based on opinion research. Moreover, the present study sought to confirm whether the sentiment explanatory capacity changes when variations in companies' characteristics associated with difficulty pricing are considered, expanding the understanding of possible sensitivities that this relationship may have in the Brazilian stock market. It is also important to highlight its relevance for market regulators who can develop measures aiming to stabilize investor sentiment, reducing market volatility and uncertainties.

In addition to this introduction, this study has five more sections. Section 2 contains a literature review addressing mispricing and investor sentiment literature; in the following section, the research hypotheses are developed based on previous studies' results. In section 4 , the methodological procedures are described, and the research results and their analyses are discussed in section 5 . The final considerations are presented in section 6 .

\section{MISPRICING AND INVESTOR SENTIMENT}

Asset pricing models have as a parameter the relationship between risk and return on assets, that is, the more volatile an asset is, the higher its return expectation (Piccoli et al., 2018). In this perspective, since the creation of 
the Capital Asset Pricing Model (CAPM), pricing models have been improved based on the identification of market anomalies. Anomalies are understood as observable patterns in the average return of assets that are at odds with pricing theories, due basically to two factors: market inefficiencies and/or lack of adequacy of the pricing model (Schwert, 2002).

Regarding the second factor, traditional finance models have been questioned for disregarding behavioral characteristics to explain abnormal asset returns (Brown \& Cliff, 2004). To bridge this gap, recent researches have sought to identify how sociological and psychological factors of human behavior may explain certain phenomena and market patterns (Kumari \& Mahakud, 2015). Behavioral finance argues that investors are beings endowed with limited rationality, who make judgments and decisions under the influence of emotional aspects (sentiments), using mental or heuristic shortcuts that lead to errors or systematic deviations.

According to De Long et al. (1990) and Brown and Cliff (2005), there are two types of investors in the capital market: arbiters and noise traders. Arbiters' decision-making is based on rational expectations about asset prices constructed over advanced analysis, while noise traders rely more on emotional factors (sentiment), following trends and impulses, given their limited rationality regarding information noises. Moreover, it can be said that market experts are also impacted by investor sentiment, since when they are assessing stock market prices, they give their opinion on the relative value by making judgments based on the information obtained and on their sentiment, reaching, sometimes, different results from other analysts or investors (Yoshinaga \& Castro, 2012). In this perspective, investor sentiment can be understood as a belief about future cash flow and risk that is not justified by economic and financial information, that is, whenever stock prices deviate from the present values of future cash flows (Baker \& Wurgler, 2006; De Long et al., 1990).

According to Baker and Wurgler (2007), another factor that can contribute to the occurrence of mispricing is the limitation of rational arbitrage, especially in short-term horizons. The latter can be associated with costs and negotiation risks generated by demand pressures and the incorporation in prices of uncertain factors, captured by investor sentiment, allowing a deviation from fundamental analysis (Neves, Gonçalves, Ribeiro, Feiteira, \& Viseu, 2016). Likewise, companies with characteristics associated with difficult pricing, such as a smaller size, high growth rate, and low stock liquidity, have limitations for arbitration and greater difficulty in the pricing of their assets (Baker \& Wurgler, 2006, 2007; Piccoli et al., 2018). 
Specifically, in smaller companies and/or companies that have a high growth perspective, the difficulty is related to the lack of historical information and uncertainty about future performance. Thus, there may be investors who defend valuations of very high or very low value with equally plausible arguments. Regarding the low stock liquidity feature, it makes the quick incorporation of available information impossible, making its pricing more imprecise.

\section{PREVIOUS STUDIES AND RESEARCH HYPOTHESIS}

Studies investigating investor sentiment in Brazil have sought to analyze its impact considering different aspects, such as its relationship with the trading volume (Marschner \& Ceretta, 2019) and with market anomalies (Xavier \& Machado, 2017), as well as its impact on accounting aspects such as earnings management, considering the moderating role of analysts (Miranda, Machado, \& Macedo, 2018), and accruals quality (Santana, Santos, Carvalho, \& Martinez, 2020). The results confirm that investor sentiment influences accounting aspects and the market phenomena in Brazil, as can be observed in more developed countries.

The research closer to the aim of the present study were developed in international markets and mainly focus on the analysis of the relationship between sentiment and return on assets, mostly identifying a positive and significant relationship between these variables (Baker \& Wrugler, 2006, 2007; Garcia, 2013; Neves et al., 2016; Piccoli et al., 2018). However, more recently, the focus has shifted to understand the role of investor sentiment in the volatility return (Aydogan, 2017; Kumari \& Mahakud, 2015; Lee et al., 2002; Smales, 2016; Schneller et al., 2018; Yu \& Yuan, 2011), which is the purpose of this study.

Moreover, empirical evidence shows that the relationship between investor sentiment and volatility may have an asymmetric behavior, that is, become more significant depending on whether the sentiment is optimistic or pessimistic (Aydogan, 2017; Kumari \& Mahakud, 2015; Smales, 2016; Yu $\&$ Yuan, 2011). Most of these researches have been performed in developed markets, such as the USA and European markets, which have investors with perceptions of risk that differ from investors in developing markets (Kumari \& Mahakud, 2015).

In the USA market, sentiment indexes based on market variables (Yu $\&$ Yuan, 2011) and newspaper news (Smales, 2016) confirm that investor 
sentiment is a priced systematic risk factor and has a more significant and negative relationship with market volatility in periods of pessimistic sentiment, confirming an asymmetric behavior. The same asymmetric behavior was identified in European markets (Aydogan, 2017; Schneller et al., 2018) and in emerging markets (Kumari \& Mahakud, 2015), confirming that asymmetry can be observed in both developed and developing markets.

These findings are justified, considering the behavior of noise traders, who withdraw from the stock market in pessimistic periods due to increased risk/volatility, allowing a higher return for other investors, since they expand their risk exposure (De Long et al., 1990). Besides, emerging markets, such as Brazil, are more vulnerable due to the higher degree of informational asymmetry and lower investor protection, causing increased uncertainty and volatility (Kumari \& Mahakud, 2015).

From this sense, although Brazil has distinct characteristics from more developed countries, it is expected an asymmetric relationship between volatility and investor sentiment with greater intensity in pessimistic periods, culminating in the first hypothesis:

- $\mathrm{H}_{1}$ : The intensity of the relationship between volatility and investor sentiment shows an asymmetric behavior.

Furthermore, Baker and Wurgler $(2006,2007)$ identified that companies in the USA market that have features associated with difficulty pricing and arbitration - new companies in terms of listing, with smaller size, which have highly volatile returns, unprofitable shares, non-dividend payers, with high growth pattern or experiencing difficulties - are more sensitive to investor sentiment. This pricing difficulty and consequent reduction in arbitrage possibilities results in a gap between the price and its fundamentals and makes the pricing of these shares more susceptible to investor sentiment.

In the Brazilian market, Piccoli et al. (2018) observed an asymmetric relationship between conditional volatility and asset returns of large companies. This result is not supported by the literature since it was expected that the explanatory capacity of the investor sentiment would be greater when companies have characteristics associated with difficult pricing, in line with the results found by Baker and Wurgler $(2006,2007)$. Thus, following the literature, the second hypothesis of the study is:

- $\mathrm{H}_{2}$ : Companies with characteristics associated with difficult pricing have greater sensitivity to investor sentiment in the Brazilian stock market. 


\section{METHODOLOGICAL PROCEDURES}

\subsection{Sample and data selection}

To represent the Brazilian stock market, we used the volatility of the IBRX100 index, as it reflects the returns of a theoretical portfolio composed of the hundred most traded shares in Brasil Bolsa Balcão (B3), as well as due to the limitation of the measures used to proxy investor sentiment, as they are only available to the market as a whole (Brown \& Cliff, 2004).

The analyzed time frame comprises data from January 2006 to December 2017 , a period defined by the availability of the variables needed for the calculation of Miranda's investor sentiment index (2018). We collected the remaining data from six data sources: 1. the B3 Investor Relations website; 2. the Economic Policy Uncertainty website of professors Baker, Bloom, and Davis; 3. the Economic Research website of the Federal Reserve Bank; 4. the Financial Economics Research Center (Nefin) website of the Faculty of Economics, Administration and Accounting of the University of São Paulo (FEA-USP); 5. the Thomson Reuters Eikon ${ }^{\circledR}$ database; and 6. the Central Bank website.

\subsection{Measurement of variables}

\subsubsection{Volatility measure}

The most common ways to estimate volatility in finance are through the models of: 1. conditional volatility (Generalized Autoregressive Conditional Heteroskedasticity - Garch); 2. stochastic volatility; 3. implied volatility; and 4. direct measures, such as realized volatility; among these models, Garchtype approaches are the most used, since they have easy estimation, precision in modeling and have flexible adaptation in relation to volatility dynamics over time (Maciel \& Ballini, 2017). In this sense, we obtained the conditional volatility by the estimation of Garch (1.1) based on the time series of the IBRX100 daily historical returns, as in equations 1 and 2:

$$
\begin{gathered}
r_{t}=\sigma_{t} \in_{t} \\
\sigma_{t}^{2}=\omega+\sum_{i=1}^{1} \alpha_{i} x_{t-i}^{2}+\sum_{j=1}^{1} \beta_{i} \sigma_{t-j}^{2}
\end{gathered}
$$


in which $r_{t}=\ln \left(\mathrm{P}_{\mathrm{t}}\right)-\ln \left(\mathrm{P}_{\mathrm{t}-1}\right)$ is the logarithmic return in $t$; $\mathrm{P}_{\mathrm{t}}$ is the price of the asset in $t ; \varepsilon_{\mathrm{t}} \sim$ i.i.d. $(0,1)$ is a zero-mean white noise, often assumed to be normal; $\sigma_{\mathrm{t}}$ is the variant volatility in time; $\sigma_{t}^{2}$, the measure of conditional volatility in month $t$; $\omega$, the constant; $\alpha_{i}$, the coefficient that measures the short-term impact of the $\epsilon_{t}$ in $\sigma_{t}^{2}$; and $\beta_{i}$, the coefficient that measures the long term impact in $\sigma_{t}^{2}$. The intuition of the Garch model is that the persistence of shocks in volatility is measured by the sum of $(\alpha+\beta)$. So, the closer to 1 , the longer the shock will take to dissipate.

\subsubsection{Investor sentiment index}

The sentiment proxies identified in the literature can be divided between opinion research variables and market variables (Baker \& Wurgler, 2006, 2007; Brown \& Cliff, 2004, 2005). Although widely used, the measures obtained through opinion research are viewed with skepticism since they may present differences between the responses of the surveyed and their real attitudes (Baker \& Wurgler, 2007; Yoshinaga \& Castro, 2012). As a result, researchers began to build measures based on market variables, highlighting the Baker and Wurgler index $(2006,2007)$ due to its ability to consistently predict future returns with significance (Xavier \& Machado, 2017).

In the Brazilian context, this index cannot be used in its original form due to the unavailability of some data in the local market (closed-end funds and dividend premium), so adaptations to the Brazilian reality are necessary (Miranda, 2018; Xavier \& Machado, 2017; Yoshinaga \& Castro, 2012). Therefore, for this study, we used the index developed and made available by Miranda (2018), which proposed an improvement of the indexes elaborated by Xavier and Machado (2017) and Yoshinaga and Castro (2012). This index is calculated monthly, and it is composed of: the number of Initial Public Offerings (IPOs), Market Advancing and Declining Ratio (Advancing and Declining - AD), Dividend Premium (PDIV), and Participation of the Individual Investors in B3's financial trading volume (PartInvInd).

According to Miranda (2018), after determining the variables, the common component between them should be extracted with the Principal Component Analysis (PCA). It is noteworthy that, before the procedure, the variables must be orthogonalized to remove the macroeconomic effects capable of generating noise in the sentiment index. To this end, the author used Baker and Wurgler's (2006) set of variables as a base, namely: gross domestic product (GDP) growth, the broad consumer price index (IPCA), the growth in consumption of durable goods, non-durable goods and 
services, employment growth and the National Bureau of Economic Research (NBER) recession indicator.

Finally, a parallel analysis was performed to evaluate the retention of principal components based on eigenvalues higher than the 95th percentile of a random sample with the same number of vectors used in PCA. Thus, being the proxies valid, the PCA was done with the orthogonalized variables resulting from the index Equation 3:

$$
\text { Sent }_{t}^{\perp}=0,474 N I P O_{t}^{\perp}+0,408 A D_{t}^{\perp}+0,551 P D I V_{t}^{\perp}+0,552 \operatorname{PartInvInd}_{t}^{\perp}
$$

Considering the Kaiser rule (eigenvalues $>1$ ) and parallel analysis, the findings suggested the permanence of the first main principal component, which explains $49 \%$ of the sample variance with orthogonalized variables, in line with Baker and Wurgler's (2007) study that found similar percentages.

For the analyses related to the asymmetric explanatory power of the investor sentiment (Sent), we segregated the sentiments in optimistic (Sent_OP) and pessimistic (Sent_PE), being the variable Sent_OP equal to the variable Sent when its values are $\geq 0$ and equal to the average of Sent_OP otherwise. The same procedure was performed for Sent_PE, considering Sent $\leq 0$ and using the average Sent_PE otherwise. We used this technique to avoid losing degrees of freedom when the sample was segregated into two groups.

\subsubsection{Characteristics of difficulty pricing}

To represent companies with characteristics of difficulty pricing, we used the portfolios elaborated and disseminated by the Nefin, constructed from the following features: size (Size), book-to-market ratio (Bm), and illiquidity (Ili). For each characteristic, three portfolios are published, rebalanced annually, containing only companies with shares traded on at least $80 \%$ of the days of the previous year. In this study, the intermediate portfolio of each characteristic was disregarded, that is, for example, we used the small and big companies' portfolios, and the medium-sized companies' portfolio was disregarded.

We ordered portfolios based on size and book-to-market by the total asset and by book value and market value ratio, respectively. We ordered the illiquidity portfolio by the degree of illiquidity of the traded shares. The selected characteristics are in line with those identified by Baker and Wurgler (2006, 2007), associated with difficulty pricing. Thus, small companies (Size_S), with a high book-to-market ratio (Bm_H) and high illiquidity 
shares (Ili_H) represent the portfolios of companies that are difficult to price; while large companies (Tam_L), companies with a low book-to-market ratio (Bm_L) and with low stock illiquidity (Ili_L) are portfolios with the opposite characteristics to the previous three.

\subsection{Econometric model}

Based on the studies of Johnman et al. (2018) and Smales (2015, 2016), to analyze the relationship between the volatility of the Brazilian stock market and the behavior of investor sentiment, we estimated Equation 4:

$$
\sigma_{t}=\alpha_{0}+\beta_{1} \sigma_{t-1}+\beta_{2} \text { Sent }_{t}+\beta_{3} P U_{t}+\beta_{4} E C_{t}+\varepsilon_{t}
$$

in which $\sigma_{t}$ represents the measure of conditional volatility in month $t$, obtained as described in section 4.2.1; $\sigma_{t-1}$ represents the conditional volatility in the month $t$-1; Sent $t_{t}$ is the investor sentiment of month $t$ of Miranda's index (2018); $P U_{t}$ is the political uncertainty (PU) in month $t$, which was measured by the index prepared by Baker, Bloom, and Davis (2016); $E C_{t}$ is a dummy variable for the economic cycle (EC), which is an indicator of economic recession for Brazil, being equal to 1 in recession and zero, otherwise; $\beta_{0} \ldots \beta_{4}$ are the parameters of the equation; and $\varepsilon_{t}$ are the residuals i.i.d.

As explained in section 4.2.1, to analyze the first hypothesis $\left(\mathrm{H}_{1}\right)$, which states that the intensity of the relationship between volatility and investor sentiment has an asymmetric behavior, we segregated the investor sentiment in Sent_OP and Sent_PE as shown in Equation 5:

$$
\sigma_{t}=\alpha_{0}+\beta_{1} \sigma_{t-1}+\beta_{2} \operatorname{Sent} \_O P_{t}+\beta_{3} \operatorname{Sent}{ }_{-} P E_{t}+\beta_{4} P U_{t}+\beta_{5} E C_{t}+\varepsilon_{t}
$$

in which Sent_OP is the optimistic sentiment in month $t$ and Sent_PE is the pessimistic sentiment in month $t$. We expected that Sent (Equation 4) had a negative and significant relationship with volatility since in periods of high sentiment, the volatility of returns is lower, as there is a greater movement in the market and a lower risk. By segregating sentiment (Equation 5), we expected non-significant behavior for Sent_OP and a negative and significant relationship with Sent_PE. This is because, in periods of optimistic sentiment, there is a higher entry of noise traders, reducing volatility; and in pessimistic periods, there is a reduction of these investors, which associated with greater uncertainty, culminates in an increase in volatility (De Long et al.,1990). 
With regard to conditional volatility in the month $t-1\left(\sigma_{t-1}\right)$, we expected a positive and significant relationship since past volatility is a good predictor for current volatility (Lee et al., 2002; Kumari \& Mahakud, 2015). As for political uncertainty (PU), we expected a positive and significant relationship, especially in developing countries, in view of the strong influence of political decisions on economic conditions (Pastor \& Veronesi, 2013). Finally, with regard to the economic cycle (EC), we expected that in periods of economic recession, there would be greater market volatility due to increased uncertainty (Pastor \& Veronesi, 2013; Smales, 2015).

To evaluate whether companies with characteristics associated with difficulty pricing are more sensitivity to sentiment $\left(\mathrm{H}_{2}\right)$, we estimated regressions considering as dependent variable the return deviations of each of the three portfolios associated with the selected characteristics (Size, Bm, and Ili), being explained by investor's sentiment, as well as by Sent_OP and Sent_PE, as shown in equations 6 and 7 :

$$
\begin{gathered}
\sigma c_{t}=\alpha_{0}+\beta_{1} \sigma c_{t-1}+\beta_{2}\left(M r-R f_{t}\right)+\beta_{3} \operatorname{Sent}_{t}+\beta_{4} P U_{t}+\beta_{5} E C_{t}+\varepsilon_{t} \\
\sigma c_{t}=\alpha_{0}+\beta_{1} \sigma c_{t-1}+\beta_{2}\left(M r-R f_{t}\right)+\beta_{3} \operatorname{Sent}_{-} O P_{t}+\beta_{4} \operatorname{Sent}{ }_{-} P E_{t}+\beta_{5} P U_{t}+\beta_{6} E C_{t}+\varepsilon_{t}
\end{gathered}
$$

in which $\sigma c_{t}$ represents the monthly standard deviation (volatility) of the daily returns of the selected portfolio with characteristics of difficulty pricing (Size, Bm and Ili), being Size_S, Bm_H, and Ili_H portfolios with characteristics of difficulty pricing and Size_L, Bm_L and Ili_L portfolios with the opposite characteristics, respectively, as detailed in section 4.2.3. $\sigma c_{t-1}$ is the volatility in $t-1 .\left(M r-R f_{t}\right)$ is the market premium risk obtained by the difference between the return of the Brazilian market (IBRX100) and the Selic rate, with which, according to the literature, is expected a negative relationship, as a drop in the return of assets increases the companies' leverage, making them riskier and more volatile (Bekaert \& Wu, 2000; Wu, 2001).

We expected that investor sentiment has a greater impact on portfolio volatility associated with difficult-to-price characteristics (Baker \& Wurgler, 2006, 2007). As for Sent_OP and Sent_PE, we expected an asymmetric behavior with greater intensity for Sent_PE due to the greater uncertainty regarding the market's behavior in this period. The other control variables follow the same explanations as equations 4 and 5 .

It is noteworthy mentioning that we grouped the data used for the regressions described in equations 4 to 7 in time series, and we defined the technique for parameter estimation after the analysis of the following tests: 
Shapiro-Wilk normality, the Breusch-Pagan homoscedasticity, the BreuschGodfrey serial correlation, and Wu-Hausman's endogeneity.

\section{DISCUSSION OF THE RESULTS}

\subsection{Exploratory analysis}

The analysis of the linear correlation between the variables can provide the first indications of the relationships that will be identified in the estimated models. In Panel A of Figure 5.1.1, it is observed that investor sentiment, considering both the complete series (Sent) and segregated into optimistic (Sent_OP) and pessimistic (Sent_PE), has a negative linear association with the volatility of the Brazilian capital market, as we expected. However, in this first analysis, there was no asymmetric behavior when Sent was segregated.

Also, in panel A, it is noted that the conditional volatility $(\sigma)$ and its lag $\left(\sigma_{-} \mathrm{d}\right)$ evidence a positive and significant linear association, confirming that past volatility is directly associated with the present volatility. PU did not evidence significant results, suggesting that there is no direct association for the sample as a whole. On the other hand, the dummy for EC demonstrates a positive and significant association, indicating that in periods of recession, there is a greater degree of uncertainty, increasing the volatility of assets.

(Figure 5.1.1)

PEARSON CORRELATION

\begin{tabular}{|c|c|c|c|c|c|c|}
\hline \multicolumn{7}{|c|}{ PANEL A } \\
\hline & $\sigma$ & $\sigma \_d$ & Sent & Sent_OP & Sent_PE & PU \\
\hline$\sigma \_d$ & $0.7542^{\star \star \star}$ & & & & & \\
\hline Sent & $-0.6701^{\star \star \star}$ & $-0.6378^{\star \star \star}$ & & & & \\
\hline Sent_OP & $-0.3896^{\star \star \star}$ & $-0.4057^{\star \star \star}$ & $0.6234^{\star \star \star}$ & & & \\
\hline Sent_PE & $-0.5944^{\star \star \star}$ & $-0.4916^{\star \star \star}$ & $0.6634^{\star \star *}$ & $0.1941^{\star \star}$ & & \\
\hline PU & 0.0529 & 0.0193 & -0.0336 & -0.0259 & 0.0155 & \\
\hline EC & $0.1842^{* \star}$ & $0.1426^{\star}$ & -0.0236 & 0.0012 & -0.1023 & -0.0316 \\
\hline
\end{tabular}




\section{(Figure 5.1 .1 (conclusion))}

\section{PEARSON CORRELATION}

\begin{tabular}{|c|c|c|c|c|c|c|}
\hline \multicolumn{7}{|c|}{ PANEL B } \\
\hline & Size_S & Size_B & Bm_H & Bm_L & Ili_H & Ili_L \\
\hline Sent & $-0.2175^{\star \star \star}$ & $-0.3120^{\star \star \star}$ & $-0.2986^{\star \star \star}$ & $-0.1853^{\star \star}$ & $-0.1890^{\star \star}$ & $-0.3085^{\star \star \star}$ \\
\hline Sent_OP & -0.1160 & -0.0852 & -0.1286 & -0.1113 & -0.1342 & -0.0906 \\
\hline Sent_PE & $-0.3571^{\star \star \star}$ & $-0.5337^{\star \star \star \star}$ & $-0.4678^{\star \star \star}$ & $-0.3211^{\star \star \star}$ & $-0,2820^{\star \star \star}$ & $-0.5183^{\star \star *}$ \\
\hline (Mr-Rf) & $-0.4048^{\star \star \star}$ & $-0.4180^{\star \star \star}$ & $-0.3762^{\star \star \star}$ & 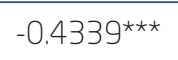 & $-0.3775^{\star \star \star}$ & $-0.4122^{\star * *}$ \\
\hline PU & -0.1358 & -0.1223 & -0.1125 & $-0.1733^{\star \star}$ & $-0,1468^{\star}$ & -0.0997 \\
\hline EC & $0.2291^{* \star *}$ & $0.1930^{* *}$ & $0.1788^{* *}$ & $0.2585^{\star \star \star}$ & $0.1985^{\star \star}$ & $0.2107^{\star \star}$ \\
\hline
\end{tabular}

Significance level: ${ }^{*} 10 \%,{ }^{* \star} 5 \%,{ }^{* \star} 1 \%$.

Source: Elaborated by the authors.

In panel B, sentiment (Sent) has a negative and significant correlation with all portfolios, and, when segregated, all associations with the optimistic sentiment (Sent_OP) are not significant, whereas, with the pessimistic sentiment (Sent_PE), they have statistical significancy. This result indicates a possible asymmetry between the types of sentiment, as supported by the literature (Baker \& Wurgler, 2006, 2007), suggesting that in periods of greater uncertainty, associated with pessimistic sentiment, assets pricing becomes less homogeneous and, therefore, it increases the volatility of the markets. In the comparison between the two portfolios for each selected characteristic, we identified no signs of asymmetry in the relationships, contrary to what we expected.

The market risk premium (Rm-Rf), in Panel B, reported a negative and significant association with all portfolios, as we expected (Bekaert \& Wu, 2000; Wu, 2001), confirming its relevance to explaining the volatility of the portfolios. As for the EC dummy, we observed a positive and significant relationship for all portfolios, indicating that when the market is in recession, the volatility of portfolio returns increase. Finally, PU showed a significant association only with the Bm_L and Ili_H portfolios, indicating that this variable may be relevant for some companies but not to explain the volatility of the market as a whole.

\subsection{Investor sentiment asymmetry in volatility}

To analyze the relationship between investor sentiment and the volatility of the Brazilian stock market, we estimated two regressions (equations 4 and 5) 
in order to observe whether the sentiment had an explanatory capacity on volatility (model I) and if there is an asymmetric behavior when the sentiment is segregated into optimistic and pessimistic (model II). The results are presented in Figure 5.2.1 and, given that the variable sentiment may present possible endogeneity problems (Kumari \& Mahakud, 2015; Miranda, 2018; Smales, 2015, 2016), we estimated two-stage least squares regressions (2SLS).

To verify the existence of endogeneity, we estimated the Wu-Hausman (WH) test, which identified that the null hypothesis of the test was rejected, that is, the variables are endogenous for both models. As instrumental variables, we used the lagged dependent and independent variables, having their relevance confirmed through the minimum eigenvalue statistic (MES) and the validity confirmed by the Sargan over-identification test. In parallel, we estimated the following tests: normality (Shapiro-Wilk), homoscedasticity (Breusch-Pagan), stationarity, and serial correlation of the residues (BreuschGodfrey).

\section{(Figure 5.2.1)}

\section{EFFECT OF SENTIMENT ASYMMETRIC ON IBRX VOLATILITY} IN THE PERIOD FROM 2010 TO 2017

\begin{tabular}{|c|c|c|c|c|c|c|c|}
\hline \multirow{2}{*}{ Variables } & \multicolumn{3}{|c|}{ Model I } & & \multicolumn{3}{|c|}{ Model II } \\
\hline & \multicolumn{2}{|c|}{ Coefficient } & Z Test & & \multicolumn{2}{|c|}{ Coefficient } & Z Test \\
\hline Sent & \multicolumn{2}{|c|}{$-0.0001^{\star \star \star}$} & -2.89 & & & & \\
\hline Sent_OP & & & & & \multicolumn{2}{|c|}{0.0001} & 0.15 \\
\hline Sent_PE & & & & & \multicolumn{2}{|c|}{$-0.0003^{\star \star \star *}$} & -5.19 \\
\hline Vol_d & \multicolumn{2}{|c|}{$0.5961^{* \star \star}$} & 8.19 & & \multicolumn{2}{|c|}{$0.4878^{\star \star \star}$} & 6.20 \\
\hline PU & \multicolumn{2}{|c|}{0.0001} & 0.68 & & \multicolumn{2}{|c|}{-0.0001} & -0.07 \\
\hline EC & \multicolumn{2}{|c|}{$0.0001^{*}$} & 1.80 & & \multicolumn{2}{|c|}{0.0001} & 1.55 \\
\hline Intercept & \multicolumn{2}{|c|}{$0.0012^{\star \star \star}$} & 5.38 & & \multicolumn{2}{|c|}{$0.0012^{* \star *}$} & 4.88 \\
\hline Wald chi2 & 0.0000 & Sargan & 0.9606 & Wald chi2 & 0.0000 & Sargan & 0.1883 \\
\hline $\mathrm{R}^{2}$ & 0.6330 & Shapiro-Wilk & 0.0000 & $\mathrm{R}^{2}$ & 0.6264 & Shapiro-Wilk & 0.0000 \\
\hline Wu-Hausman & 0.0217 & $B P$ & 0.000 & Wu-Hausman & 0.0496 & $B P$ & 0.0000 \\
\hline MES I & 105.356 & $B G$ & 0.3039 & MESI & 17.276 & $B G$ & 0.2692 \\
\hline MES II & - & Obs.: & 142 & MES II & 47.509 & Obs.: & 142 \\
\hline
\end{tabular}

Estimated standard error with correction for heteroscedasticity. According to the Variance Inflation Factor (VIF), there was no multilinearity problem. The stationarity tests confirm that all variables do not have a unit root. Significance level: ${ }^{\star} 10 \%,{ }^{\star \star \star} 1 \%$. 
Based on the results shown in Figure 5.2.1, in all models, the hypothesis of homoscedasticity of variances was rejected at $1 \%$ (Breusch-Pagan test), as well as the hypothesis of normality of the residues, according to the ShapiroWilk test. However, considering the Central Limit Theorem, the assumption of normality can be relaxed. As for the null hypothesis of autocorrelation, Breusch-Godfrey test, it is clear that the null hypothesis was not rejected. In this sense, we estimated standard errors with correction for heteroscedasticity.

The results of model I, presented in Figure 5.2.1, confirm that the Brazilian stock market volatility is explained by investor sentiment, as we expected. The negative relationship indicates that volatility in optimistic periods is lower. This statement is ratified in Model II since the relationship of Sent_PE with volatility is significant (-5.19) while Sent_OP does not show a significant relationship, confirming an asymmetric behavior with a stronger relationship when the sentiment is pessimistic.

The results are in line with the literature, since the pessimistic sentiment causes greater uncertainty in the market, culminating in higher volatility (De Long et al., 1990), while in optimistic periods, there is a higher entry of noise traders associated with the positive market trend, which causes a reduction on the volatility. Thus, it can be affirmed that variations in investor sentiment impact the volatility of the Brazilian stock market with different intensities, having greater explanatory power when the sentiment is pessimistic, as stated in $H_{1}$ hypothesis. This same behavior was observed mainly in developed markets (Aydogan, 2017; Smales, 2016; Yu \& Yuan, 2011), but also in developing markets (Kumari \& Mahakud, 2015).

Regarding the control variables, the results were similar in both models. The lagged conditional volatility $\left(\sigma_{-} \mathrm{d}\right)$ had a positive and significant relationship, being the most significant variable in the estimation. The economic cycle dummy (EC) was significant only in Model I, indicating that in recessive periods there is higher IBRX volatility when the sample is considered as a whole, as we expected, as there is a greater degree of uncertainty associated with pricing. On the other hand, political uncertainty (PU) was not significant, indicating that it is not relevant to explain volatility.

\subsection{Investor sentiment asymmetry in company characteristics}

In order to verify if changes in the characteristics of the companies could cause an asymmetric behavior in the explanatory capacity of investor sentiment, we regressed the volatility of the portfolio of companies with characteristics associated with difficulty pricing (small size, high book-to-market, and high illiquidity) in relation to sentiment. These results were compared 
with the regression results considering the opposite characteristics (large companies, low book-to-market, and low illiquidity), in which lower statistical significance was expected. The procedures for estimating and the selection of instruments followed the same pattern described above. The results of the Equation 6 estimation are presented in Figure 5.3.1.

\section{(Figure 5.3.1)}

RELATIONSHIP BETWEEN PORTFOLIOS ASSOCIATED WITH COMPANY CHARACTERISTICS AND ASYMMETRIC BEHAVIOR OF INVESTOR SENTIMENT

\begin{tabular}{|c|c|c|c|c|c|c|}
\hline & \multicolumn{3}{|c|}{ Difficulty pricing } & \multicolumn{3}{|c|}{ Opposite characteristic } \\
\hline & Size_S & Bm_H & Ili_H & Size_L & Bm_L & Ili_L \\
\hline \multirow[t]{2}{*}{ Sent } & $-0.0007^{\star \star}$ & $-0.0007^{\star \star \star}$ & $-0.0005^{\star}$ & $-0.0012^{\star \star \star}$ & $-0.0005^{\star}$ & $-0.0013^{\star \star}$ \\
\hline & $(-2.21)$ & $(-2.26)$ & $(-1.94)$ & $(-2.57)$ & $(-1.67)$ & $(-2.49)$ \\
\hline \multirow[t]{2}{*}{$\sigma \_d$} & $0.3172^{\star \star \star}$ & $0.4747^{\star \star \star *}$ & $0.3254^{\star \star \star}$ & $0.5186^{\star \star \star}$ & $0.3853^{\star \star \star}$ & $0.5267^{\star * \star}$ \\
\hline & $(4.27)$ & $(6.81)$ & $(4.36)$ & $(7.38)$ & $(3.64)$ & $(7.58)$ \\
\hline \multirow[t]{2}{*}{ (Mr-Rf) } & $-0.0354^{\star \star \star}$ & $-0.0359 * \star \star$ & $-0.0299 * \star \star$ & 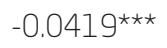 & $-0.0391^{\star \star \star}$ & $-0.0439 * \star \star$ \\
\hline & $(-5.20)$ & $(-5.66)$ & $(-4.90)$ & $(-6.27)$ & $(-3.24)$ & $(-6.05)$ \\
\hline \multirow[t]{2}{*}{ PU } & -0.0012 & -0.0011 & $-0.0012^{*}$ & $-0.0016^{\star \star}$ & $-0.0020^{\star \star}$ & $-0.0015^{\star}$ \\
\hline & $(-1.56)$ & $(-1.54)$ & $(-1.74)$ & $(-2.00)$ & $(-2.37)$ & $(-1.77)$ \\
\hline \multirow[t]{2}{*}{ EC } & 0.0009 & 0.0003 & 0.0007 & 0.0003 & 0.0011 & 0.0005 \\
\hline & $(1.18)$ & $(0.48)$ & $(0.94)$ & $(0.38)$ & $(1.30)$ & $(0.58)$ \\
\hline \multirow[t]{2}{*}{ Intercept } & $0.0078^{\star \star \star}$ & $0.0057^{\star \star \star}$ & $0.0071^{\star \star \star}$ & $0.0060^{\star * \star}$ & $0.0078^{\star \star \star}$ & $0.0063^{\star * *}$ \\
\hline & $(7.84)$ & (6.35) & $(7.77)$ & $(6.00)$ & $(5.72)$ & $(5.87)$ \\
\hline Wald & 0.0000 & 0.0000 & 0.0000 & 0.0000 & 0.0000 & 0.0000 \\
\hline $\mathrm{R}^{2}$ & 0.3360 & 0.4515 & 0.3074 & 0.5439 & 0.4061 & 0.5425 \\
\hline WH & 0.0490 & 0.0331 & 0.0494 & 0.0161 & 0.0458 & 0.0253 \\
\hline MES I & 125.76 & 90.297 & 174.02 & 26.683 & 73.589 & 27.267 \\
\hline Sargan & 0.2720 & 0.0792 & 0.8638 & 0.0873 & 0.7342 & 0.1152 \\
\hline SW & 0.0000 & 0.0000 & 0.0000 & 0.0000 & 0.0000 & 0.0000 \\
\hline $\mathrm{BP}$ & 0.000 & 0.000 & 0.0000 & 0.000 & 0.000 & 0.0001 \\
\hline$B G$ & 0.5034 & 0.3312 & 0.2664 & 0.2643 & 0.1956 & 0.4330 \\
\hline
\end{tabular}

${ }^{1}$ Estimated standard error with correction for heteroscedasticity. ${ }^{2}$ According to the VIF, there was no multilinearity problem. ${ }^{3}$ The stationarity tests confirm that all variables do not have a unit root. ${ }^{4}$ Significance level: * $10 \%$, ${ }^{* *} 5 \%$, $\star * \star 1 \%$, 
Comparing the results of the relationship between investor sentiment and the volatility of the two portfolios for each of the characteristics, it is observed that all of them had an asymmetric behavior. However, only the book-to-market ratio characteristic reported results as expected by the literature (Barker \& Wurgler, 2006, 2007), that is, the portfolio associated with difficulty pricing $\left(\mathrm{Bm}_{-} \mathrm{H}\right)$ showed a significant relationship, while the opposite portfolio presented less significance $\left(\mathrm{Bm}_{-} \mathrm{L}\right)$. These results suggest that companies with a high expectation of growth have a greater susceptibility to investor sentiment, confirming hypothesis $\mathrm{H}_{2}$ for this characteristic.

In the relationships of the portfolios segmented by size and illiquidity, we observed a lower significance in the relationship with the volatility of the portfolio of small (Size_S) and more illiquid companies (Iliq_H) when compared to the volatility for large (Size_L) and less illiquid companies (Iliq_L). This result is not supported by the literature, since Size_S and Iliq_H portfolios were expected to be more difficult to be priced and, therefore, their volatility would be more strongly influenced by sentiment than their opposite characteristics, which have their pricing based on more predictable factors (Barker \& Wurgler, 2006, 2007).

A possible explanation for these results may be associated with the way in which investors operate in the Brazilian market and their specific characteristics. According to De Long et al. (1990), the noise traders theory operates in the markets in a way that volatility is reduced at optimistic periods, and in pessimistic periods they withdraw from the market so that investor sentiment can explain volatility. Given the Brazilian market development and the preference of Brazilian investors for large companies (Machado \& Medeiros, 2011), these noise traders possibly operate investing in large companies in the local market, which, when compared to companies from other markets, can often be considered small. Another factor that should be considered regarding the size is the possibility of results being influenced by companies' survival bias (Malkiel, 2003), which may be stronger in markets that are not yet consolidated.

Moreover, given the risks of operating in developing markets, investors concentrate their operation on more liquid shares, which enables the repositioning of their investments quicker. It is worth noting that the larger companies are also the ones with the highest share liquidity in the Brazilian market (Machado \& Medeiros, 2011), so it is coherent that the two characteristics evidence similar results.

Given that, it is possible to affirm that investments in small and more illiquid companies are less exposed to noise traders' operations and have greater difficulty in incorporating new information. Therefore, investor 
sentiment will have a lower capacity to be significant to explain the volatility of these portfolios in the Brazilian market. Considering these factors, it would be coherent to state that, due to the particular characteristics of the Brazilian market, investor sentiment can be considered a relevant factor to explain volatility asymmetrically.

The relationship between volatility and market risk premium was negative and significant in all portfolios, as we expected, evidencing that in periods of low sentiment, there is an increase in the returns and, consequently, a higher market risk premium (Bekaert \& Wu, 2000). The dummy for EC did not evidence significant relationships in all regressions, indicating that the economic situation does not have explanatory capacity on the volatility of the returns of this sample, regardless of the characteristics of companies in the Brazilian market.

It is interesting to note that political uncertainty (PU) was not relevant to explain the volatility of the market as a whole (Figure 5.2.1), but when volatility was segregated by companies' characteristics (Figure 5.3.1), we observed a negative and significant relationship with most portfolios, in line with the literature. This result may be associated with the fact that from 2014 on, there was an escalation in the series of news associated with PU in Brazil, with a peak in 2016, due to the presidential impeachment, which was seen by the market as a positive event for the capital market, changing the expected direction of the relationship.

Seeking to enhance the understanding of the relationships observed in Figure 5.3.1, we performed a more detailed analysis of the effect of optimistic and pessimistic sentiment on the volatility of companies with different characteristics. The results of the regressions (Equation 7) followed the standards adopted on the previous estimates and are reported in Figure 5.3.2.

When sentiment is segregated, it can be confirmed that pessimistic sentiment concentrates the explanatory capacity of the portfolio's volatility, that is, there is an asymmetry, as we expected. In the comparative analysis between the portfolios and their opposite characteristics, it is again noticed that all portfolios have an asymmetric behavior. However, only the book-to-market ratio characteristic $\left(\mathrm{Bm}_{-} \mathrm{H}\right)$ evidenced asymmetry as we expected, and the other two characteristics (size and illiquidity) in an opposite way to the expected, similar to the behavior observed in Figure 5.3.1. This result reinforces the perception that the Brazilian market has distinctive characteristics in relation to developed markets, turning sentiment important to explain the volatility of large companies and with high liquidity on shares. Finally, political uncertainty showed negative and significant relationships, and the economic cycle dummy was not significant, in line with the results of Figure 5.3.1. 


\section{(Figure 5.3.2)}

RELATIONSHIP BETWEEN PESSIMISTIC AND OPTIMISTIC INVESTOR SENTIMENT AND PORTFOLIOS ASSOCIATED WITH CHARACTERISTICS OF COMPANIES THAT ARE DIFFICULT TO PRICE

\begin{tabular}{|c|c|c|c|c|c|c|}
\hline & \multicolumn{3}{|c|}{ Difficulty pricing } & \multicolumn{3}{|c|}{ Opposite characteristic } \\
\hline & Size_S & Bm_H & III_H & Size_L & Bm_L & Ili_L \\
\hline \multirow[t]{2}{*}{ Sent_OP } & -0.0005 & 0.0008 & -0.0004 & 0.0015 & -0.0001 & $-0.0017^{\star}$ \\
\hline & $(-0.42)$ & $(0.79)$ & $(-0.54)$ & $(1.63)$ & $(-0.15)$ & $(-1.68)$ \\
\hline \multirow[t]{2}{*}{ Sent_PE } & $-0.0015^{\star}$ & $-0.0026^{\star \star \star}$ & $-0.0011^{\star}$ & $-0.0026^{\star \star \star}$ & -0.0012 & $-0.0029^{\star \star \star}$ \\
\hline & $(-1.83)$ & $(-3.11)$ & $(-1.67)$ & $(-2.89)$ & $(-1.54)$ & $(-3.01)$ \\
\hline \multirow[t]{2}{*}{$\sigma \_d$} & $0.3003^{\star \star \star}$ & $0.4099 * \star \star$ & $0.3181^{\star \star \star}$ & $0.4897^{\star \star \star}$ & $0.3742^{\star \star \star}$ & $0.4928^{\star \star \star}$ \\
\hline & (3.89) & $(5.36)$ & $(4.18)$ & $(6.66)$ & $(5.20)$ & $(6.80)$ \\
\hline \multirow[t]{2}{*}{ (Mr-Rf) } & $-0.0350^{\star \star \star}$ & $-0.0355^{\star \star \star}$ & $0.0296^{\star \star \star}$ & $-0.0425^{\star \star \star}$ & $-0.0389 * \star \star$ & $-0.0445^{\star \star \star}$ \\
\hline & $(-5.09)$ & $(-5.48)$ & $(-4.78)$ & $(-6.43)$ & $(-5.60)$ & $(-6.16)$ \\
\hline \multirow[t]{2}{*}{ PU } & $-0.0014^{\star}$ & $-0.0015^{\star}$ & $-0.0013^{*}$ & $-0.0019^{\star \star}$ & $-0.0021^{\star \star \star}$ & $-0.0019^{\star \star}$ \\
\hline & $(-1.71)$ & $(-1.92)$ & $(-1.85)$ & $(-2.42)$ & $(-2.57)$ & $(-2.18)$ \\
\hline \multirow[t]{2}{*}{ EC } & 0.0009 & 0.0002 & 0.0006 & 0.0001 & 0.0010 & 0.0003 \\
\hline & $(1.10)$ & $(0.31)$ & $(0.85)$ & $(0.16)$ & $(1.22)$ & $(0.38)$ \\
\hline \multirow[t]{2}{*}{ Intercept } & $0.0071^{\star \star \star}$ & $0.0014^{\star \star}$ & $0.0067^{\star \star \star \star}$ & $0.0029 \star \star$ & $0.0071^{\star \star \star}$ & $0.0029 * \star$ \\
\hline & $(4.36)$ & $(2.48)$ & $(4.85)$ & $(2.23)$ & $(4.17)$ & $(2.07)$ \\
\hline Wald & 0.0000 & 0.0000 & 0.0000 & 0.0000 & 0.0000 & 0.0000 \\
\hline $\mathrm{R}^{2}$ & 0.3263 & 0.4321 & 0.2928 & 0.5546 & 0.3982 & 0.5470 \\
\hline WH & 0.0385 & 0.0067 & 0.0255 & 0.0387 & 0.0490 & 0.0334 \\
\hline MES I & 34.932 & 36.193 & 40.497 & 44.989 & 25.846 & 45.079 \\
\hline MES II & 95.335 & 80.642 & 68.019 & 47.908 & 75.3953 & 50.545 \\
\hline Sargan & 0.7235 & 0.1029 & 0.2543 & 0.1324 & 0.1780 & 0.0881 \\
\hline SW & 0.0000 & 0.0000 & 0.0000 & 0.0000 & 0.0000 & 0.0000 \\
\hline $\mathrm{BP}$ & 0.0000 & 0.0000 & 0.0000 & 0.0000 & 0.0000 & 0.0000 \\
\hline BG & 0.4417 & 0.2450 & 0.2506 & 0.2284 & 0.1712 & 0.4116 \\
\hline
\end{tabular}

${ }^{1}$ Estimated standard error with correction for heteroscedasticity. ${ }^{2}$ According to the VIF, there was no multilinearity problem. ${ }^{3}$ The stationarity tests confirm that all variables do not have a unit root. ${ }^{4}$ Significance level: * $10 \%$, ${ }^{* *} 5 \%$,

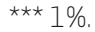


Additional analyzes were performed with an alternative proxy for investor sentiment, based on opinion research, the Consumer Confidence Index of the Getulio Vargas Foundation (ICC/FGV). The results were not consistent with those observed by the sentiment proxy based on market variables, confirming previous studies findings that proxies based on opinion research are not efficient measures to proxy investor sentiment since they may have differences between the surveyed responses and their real attitudes (Baker \& Wurgler, 2006, 2007; Miranda, 2018; Xavier \& Machado, 2017; Yoshinaga \& Castro, 2012; Piccoli et al., 2018). Due to space limitations, the results were not reported in the article.

\section{CONCLUSION}

The aim of this study was to deepen the discussions related to the explanatory capacity of investor sentiment in the Brazilian stock market, seeking to confirm not only its relevance but also to verify the existence of asymmetric behaviors caused by variations in sentiment and by companies' characteristics associated with difficulty pricing.

The relationship identified between volatility and investor sentiment was negative and significant, confirming that the volatility of the Brazilian market is explained by investor sentiment. Moreover, this relationship showed an asymmetric behavior, with the pessimistic sentiment having a greater explanatory capacity about volatility. This behavior was observed in a similar way in developed markets, suggesting that, although there are distinct risk perceptions in these markets, since the emerging ones are considered more vulnerable, the asymmetric impact of investor sentiment occurs in a similar way.

When analyzing the explanatory power of sentiment in relation to the volatility of portfolios of companies that have characteristics associated with difficult pricing, an asymmetric behavior of the explanatory power of sentiment was also observed. However, only the book-to-market ratio reported relationships similar to those identified in developed markets, that is, the volatility of companies with greater growth opportunities, which are more difficult to be priced, can be explained by investor sentiment with greater intensity than their opposite characteristic.

Considering portfolios built based on the characteristics of size and illiquidity, the volatility of the portfolio of large and less illiquid companies was more strongly explained by investor sentiment, contrary to the results identified in developed markets. This result may be associated with particularities 
of the local market, in particular the role of noise traders in the capital market, as these are generally concentrated in shares of large companies and with greater liquidity. In addition, the largest companies in the local market can be considered small when compared to companies in developed countries, and the market monitoring is concentrated in large companies, providing a greater volume of information that can influence investor sentiment. Finally, it is possible that the result is impacted by the survival bias. It is noteworthy mentioning that the largest companies are also the ones with the most liquid shares; thus, it is coherent that the portfolios of these characteristics present similar behaviors.

Regardless of the results for the size and illiquidity characteristics different from those identified in developed markets, this result shows that the impact of sentiment on volatility may be sensitive to companies' characteristics, relevant information for greater accuracy in asset pricing.

Finally, we sought to verify whether the variation in sentiment (optimistic and pessimistic) associated with the characteristics of difficulty pricing of companies evidences an asymmetric behavior. In line with the results observed for the sample as a whole, an asymmetric behavior of sentiment was identified, being significant only in pessimistic periods, as expected.

The study contributes to the advancement of the literature related to sentiment, as it documents its effect not only on market volatility but also on the identification of factors that can generate asymmetries in the explanatory power of sentiment, making it possible to observe its specificities and behaviors in the Brazilian market, which are distinct from those observed in developed markets. This identification enhances the understanding of the volatility behavior in emerging markets, markets that attract investors from all parts of the world, enabling the development of more accurate strategies for obtaining additional profits. Moreover, it indicates to market regulator factors that can be stabilized in order to reduce asset volatility.

\section{IMPACTO ASSIMÉTRICO DO SENTIMENTO DO INVESTIDOR NA VOLATILIDADE DO MERCADO ACIONÁRIO BRASILEIRO}

\section{RESUMO}

Objetivo: O objetivo deste estudo foi analisar o efeito do sentimento do investidor sobre a volatilidade do mercado acionário brasileiro. Especificamente, buscou-se identificar se o comportamento assimétrico do 
sentimento pode ser observado em mercados emergentes, considerando empresas que possuem características de difícil precificação.

Originalidade/valor: Diferentemente da maioria dos estudos sobre sentimento do investidor, este foca seu impacto na volatilidade do mercado acionário, assim como nas características das empresas associadas à difícil precificação.

Design/metodologia/abordagem: Utilizou-se a volatilidade do índice IBRX100 para representar o mercado acionário brasileiro, e, como proxy para sentimento do investidor, selecionou-se o índice de Miranda (2018) baseado em dados de mercado. Para as estimações, adotou-se a técnica de mínimos quadrados em dois estágios (MQ2E), tendo em vista problemas com endogeneidade. Por fim, segregou-se a volatilidade das empresas em características de difícil precificação, para analisar a sensibilidade delas ao sentimento.

Resultados: Os resultados indicam que o sentimento tem relação negativa e significativa com a volatilidade do mercado acionário brasileiro, bem como evidenciam um comportamento assimétrico, sendo mais forte estatisticamente em períodos pessimistas. Análises adicionais demonstraram que a capacidade explicativa do sentimento é sensível às características das empresas, mas somente aquelas com alto book-to-market evidenciaram o comportamento assimétrico conforme esperado pela literatura. Os portfólios segmentados por tamanho e iliquidez mantiveram um comportamento assimétrico, mas a volatilidade das grandes empresas e das menos ilíquidas foi mais bem explicada pelo sentimento, indicando que o mercado brasileiro apresenta características distintivas em relação a mercados desenvolvidos.

\section{PALAVRAS-CHAVE}

Volatilidade. Sentimento do investidor. Assimetria. Precificação de ativos. Mispricing.

\section{REFERENCES}

Aydogan, B. (2017). Sentiment dynamics and volatility of international stock markets. Eurasian Business Review, 7(3), 407-419. doi:10.1007/s408 21-016-0063-3 
Baker, M., \& Wurgler, J. (2006). Investor sentiment and the cross-section of stock returns. Journal of Finance, 61 (4), 1645-1680. doi:10.1111/j.15406261.2006.00885.x

Baker, M., \& Wurgler, J. (2007). Investor sentiment in the stock market. Journal of Economic Perspectives, 21 (2), 129-151. doi:10.1257/jep.21.2.129

Baker, S., Bloom, N., \& Davis, S. J. (2016). Measuring economic policy uncertainty. Quarterly Journal of Economics, 131 (4), 1593-1636. doi:10.1093/ qje/qjw024

Bekaert, G., \& Wu, G. (2000). Asymmetric volatility and risk in equity markets. The Review of Financial Studies, 13(1), 1-42. doi:10.1093/rfs/13.1.1

Brown, G. W., \& Cliff, M. T. (2004). Investor sentiment and the near-term stock market. Journal of Empirical Finance, 11(1), 1-27. doi:10.1016/j. jempfin.2002.12.001

Brown, G. W., \& Cliff, M. T. (2005). Investor sentiment and asset valuation. The Journal of Business, 78(2), 405-440. doi:10.1086/427633

De Long, J. B., Shleiger, A., Summers, L. H., \& Waldmann, R. J. (1990). Noise trader risk in financial markets. Journal of Political Economy, 98(4), 703-738.

Federal Reserve Bank of St. Louis (2017). OECD based recession indicator for Brazil from the period following the peak through the trough. Recuperado de https://fred.stlouisfed.org/tags/series?t=brazil\%3Boecd\%3 Brecession\%20indicators\&ob $=$ pv\&od $=$ desc

Galdi, F. C., \& Gonçalves, A. M. (2018). Pessimismo e incerteza das notícias e o comportamento dos investidores no Brasil. Revista de Administração de Empresas, 58(2), 130-148. doi:10.1590/s0034-759020180203

Garcia, D. (2013). Sentiment during recession. The Journal of Finance, LXVIII(3), 1267-1300. doi:10.1111/jofi.12027

Johnman, M., Vanstone, B. J., \& Gepp, A. (2018). Predicting FTSE 100 returns and volatility using sentiment analysis. Accounting $\mathcal{E}$ Finance, 58, 253-274. doi:10.1111/acfi.12373

Kumari J., \& Mahakud, J. (2015). Does investor sentiment predict the asset volatility? Evidence from emerging stock market India. Journal of Behavioral and Experimental Finance, 8, 25-39. doi:10.1016/j.jbef.2015.10.001

Lee, W. Y., Jiang, C. X., \& Indro, D. C. (2002). Stock market volatility, excess returns, and the role of investor sentiment. Journal of Banking \& Finance, 26(12), 2277-2299. doi:10.1016/S0378-4266(01)00202-3 
Machado, M. A. V., \& Medeiros, O. R. (2011). Modelos de precificação de ativos e o efeito liquidez: Evidências empíricas no mercado acionário brasileiro. Revista Brasileira de Finanças, 9(3), 383-412. doi:10.12660/rbfin. v9n3.2011.2862

Maciel, L. S., \& Ballini, R. (2017). Modelagem e previsão do valor em risco com modelos de volatilidade baseada em variação: Evidências empíricas. Revista de Contabilidade e Finanças, 28(75), 361-376. doi:10.1590/1808057x201704140

Malkiel, B. G. (2003). The efficient markets hypothesis and its critics. Journal of Economic Perspectives, 17(1), 59-82. doi:10.1257/089533003321164958

Marschner, P. F., \& Ceretta, P. S. (2019). Como o volume de negociação reage ao sentimento do investidor? Revista de Contabilidade e Organizações, 13, e163596. doi:10.11606/issn.1982-6486.rco.2019.163596

Miranda, K. F. (2018). Sentimento do investidor e a influência do horizonte de investimento em decisões corporativas: Evidências baseadas na Teoria de Catering (Tese de doutorado, Universidade Federal da Paraíba, João Pessoa, PB, Brasil). Recuperado de http://www.ccsa.ufpb.br/ppgcc/contents/teses/tese-003kleber-formiga-miranda.pdf/view

Miranda, K. F., Machado, M. A. V., \& Macedo, L. A. F. (2018). Sentimento do investidor e gerenciamento de resultados: O monitoramento dos analistas importa? Revista de Administração Mackenzie, 19 (4), 1-29. doi:10.1590/16786971/eRAMF180104

Neves, M. E. D., Gonçalves, L. M. A. D., Ribeiro, M. J. S., Feiteira, P. J. S., \& Viseu, C. M. P. (2016). Relação unidirecional entre confiança do consumidor e rentabilidade do PSI - 20: Influência do ciclo econômico. Revista de Contabilidade e Finanças, 27(72), 363-377. doi:10.1590/1808-057X2016 02280

Núcleo de Pesquisa em Economia Financeira (2018). IVol-Br Volatility Index. Recuperado de http://nefin.com.br/volatility_index.html

Pastor, L., \& Veronesi, P. (2013). Political uncertainty and risk premia. Journal of Financial Economics, 110, 520-545. doi:10.1016/j.jfineco.2013.08.007

Piccoli, P., Costa, N. C. da, Jr., Silva, W. V. da, \& Cruz, J. A. (2018). Investor sentiment and the risk-return trade-off in the Brazilian market. Accounting E Finance, 58, 599-618. doi:10.1111/acfi.12342

Santana, C. V. S., Santos, L. P. G., Carvalho, C. V. O., Jr., \& Martinez, A. L. (2020). Sentimento do investidor e gerenciamento de resultados no Brasil. Revista Contabilidade \& Finanças, 31 (83), 283-301. doi:10.1590/1808-057x 201909130 
Schneller, D., Heiden, S., \& Hamid, A. (2018). Home is where you know your volatility: Local investor sentiment and stock market volatility. German Economic Review, 19(2), 209-236. doi:10.1111/geer.12125

Schwert, G. W. (2002). Anomalies and market efficiency. University of Pennsylvania - Department of Finance. Recuperado de http://ssrn.com/ abstract_id $=338080$

Smales, L. A. (2015). Asymmetric volatility response to news sentiment in gold futures. Journal of International Financial Markets, Institutions and Money, 34, 161-172. doi:10.1016/j.intfin.2014.11.001

Smales, L. A. (2016). Time-varying relationship of news sentiment, implied volatility and stock returns. Applied Economics, 48(51), 4942-4960. doi:10. 1080/00036846.2016.1167830

Wu, G. (2001). The determinants of asymmetric volatility. The Review of Financial Studies, 14(3), 837-859. doi:10.1093/rfs/14.3.837

Xavier, G. C., \& Machado, M. A. V. (2017). Anomalies and investor sentiment: Evidences in the Brazilian market. Brazilian Administration Review, 14(3), 1-25. doi:10.1590/1807-7692bar2017170028

Yoshinaga, C. E., \& Castro, F. H. F., Jr. (2012). The relationship between market sentiment index and stock rates of return: A panel data analysis. Brazilian Administration Review, 9(2), 189-210. doi:10.1590/S1807-76922 012000200005

Yu, J., \& Yuan, Y. (2011). Investor sentiment and the mean-variance relation. Journal of Financial Economics, 100(2), 367-381. doi:10.1016/j.jfineco. 2010.10.011

\section{AUTHOR NOTES}

Talieh S. V. Ferreira, Ph.D. from the Department of Management, Federal University of Paraíba (UFPB); Márcio A. V. Machado, Ph.D. from the Department of Management, University of Brasília (UnB); Polyandra Z. P. Silva, MSc. from the Department of Accounting, University of Brasília (UNB).

Talieh S. V. Ferreira is now a research fellow at Center for Research on Finance and Accounting (GFIC) and Center for Research on Accounting and Capital Markets (Necmec) of UFPB; Márcio A. V. Machado is now an associate professor at the Department of Management of UFPB; Polyandra Z. P. Silva is now an assistant professor at the Department of Accounting of Federal University of Cariri (Ufca).

Correspondence concerning this article should be addressed to Talieh S. V. Ferreira, Cidade Universitária, campus I, Castelo Branco, João Pessoa, Paraíba, Brazil, CEP 58051-900.

E-mail: taliehv@gmail.com 


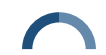

Talieh S. V. Ferreira, Márcio A. V. Machado, Polyandra Z. P. Silva

EDITORIAL BOARD

Editor-in-chief

Gilberto Perez

Associate editor

David Ferreira Lopes Santos

Technical support

Vitória Batista Santos Silva

\section{EDITORIAL PRODUCTION}

Publishing coordination

Jéssica Dametta

Language editor

Daniel de Almeida Leão

Layout designer

Emap

Graphic designer

Libro 